\title{
Quality Changes of White Shrimp (Litopenaeus vannamei) Treated with Potassium Sorbate and Sodium Metabisulphite: A Comparative Study
}

\author{
A. Jeyakumari*, Jesmi Debbarma, S. Remya, C.N. Ravishankar, \\ A.A. Zynudheen, George Ninan and K.V. Lalitha
}

ICAR- Central Institute of Fisheries Technology, Cochin- 682 029, India

*Corresponding author

\section{A B S T R A C T}

Keywords

White shrimp, Ice storage, Quality, Dip treatment

Article Info

Accepted:

12 October 2019

Available Online:

10 November 2019
The present study evaluated the quality changes of potassium sorbate (PS$1.5 \%)$, sodium metasulphite (SMB-1.25\%) dip treated white shrimps (Litopenaeus vannamei) stored under ice. White shrimp had a protein content of $18.8 \%$. Fatty acid composition of shrimp meat revealed that, white shrimp had higher polyunsaturated fatty acids (PUFA) content $(44.73 \%)$ followed by saturated fatty acids $(35.45 \%)$ and monounsaturated fatty acids (19.65\%). Biochemical quality indices such as $\mathrm{pH}$, total volatile base, trimethylamine content and thiobarbituric acid value showed an increased trend during storage. The texture profile analysis showed decreased trend in hardness of shrimp meat during storage. Sensory analysis showed that PS and SMB treated sample had higher score for overall acceptability than control. Microbial analysis revealed that quality of white shrimps under ice storage had a shelf life up to 9, 12, 15days, respectively for control, SMB and PS treated samples.

\section{Introduction}

Shrimps are rich in protein, low fat and calories (Chen et al., 2013). Litopeneus vanname $i$ is generally referred as pacific white shrimp or white leg shrimp. It has become more popular species of shrimp cultured in India and worldwide. Moreover, it occupies nearly $90 \%$ in the global aquaculture shrimp production. In India, the marine product exports reached USD 7.08 billion during the year 2017-2018. Frozen shrimp had higher contribution of $68.46 \%$. Among this $76.45 \%$ from the cultured shrimp in the total shrimp exported. It may be due to the adoption of Litopenaeus vannamei culture in India. The export of L. vannamei was 4, 02, 374 MT during 2017-18 (MPEDA, 2018). Shrimps are 
highly perishable due the presence of higher amount of free amino-acids and other soluble non-nitrogenous substances which results in limited shelf life (Zeng et al., 2005). Chilling or icing is the most common preservative method used worldwide to preserve the food products which retains the taste and nutritional value (Campanone et al., 2002). However, quality and shelf life of shrimp during iced or refrigerated storage is limited due to microbiological enzymatic activity and melanosis. Due to increasing demand for fresh and processed shrimp, both industry and researchers are focusing to extend the shelf life of shrimp and shrimp products. Several studies have been conducted for shelf life extension of fish and shell fish with a range of natural and synthetic preservatives. However, the seafood processors are still using sodium metabisulphite dip treatment for preserving the quality of shrimp. It has been reported that sulphites and their derivatives are widely used as polyphenol oxidase inhibitors for controlling melanosis in shrimps (Montero et al., 2001). Manju et al., (2007) observed extended shelf life of potassium sorbate / sodium acetate treated fish than control. Thomas (2000) reported that potassium sorbate is known to inhibit a wide range of bacteria and have numerous advantages as food preservatives and also its greater solubility extends the usage of sorbate as a solution suitable for dipping and spraying. Based on the above information, the present work was undertaken to study the effect of potassium sorbate (PS)/sodium metabisulphite (SMB) dip treatment on the quality and shelf life of white shrimp under iced storage.

\section{Materials and Methods}

\section{Sample preparation}

Fresh pacific white shrimp (Litopenaeus vannamei) with the average weight of $30 \pm 2.0$ $\mathrm{g}$ and length $18 \pm 1.0 \mathrm{~cm}$ were purchased from an Aqua farm at Kokilamedu, Chennai, India and are divided into three lots. First and second lots were dip treated with potassium sorbate (PS), sodium metabisulphite (SMB) solution at the concentrations of $1.5 \%$ and $1.25 \%$, respectively for 3 minutes. Third lot which was kept as control (C- without treated).All the samples were kept in an insulated ice box and brought to laboratory for the further analysis with iced condition(1:1, shrimp/ice).All the sample boxes kept at chill room $\left(2^{\circ}-3^{\circ} \mathrm{C}\right)$ to avoid rapid melting of ice and required ice were replaced to compensate the melted ice. The samples were analysed up to 15 days at known interval periods.

\section{Biochemical, microbiological and sensory analysis}

Proximate composition of shrimp meat was analyzed according to AOAC, (2005). For fatty acid analysis, the fat was extracted from fresh shrimp meat by Folch et al., (1957) and fatty acid composition analysis was performed using Gas Chromatography (Varian, CP3800). $\mathrm{pH}$ of shrimp meat was determined by using calibrated glass electrode $\mathrm{pH}$ meter (Cyberscan 510; Eutech Instruments, Singapore). Total volatile base nitrogen (TVB$\mathrm{N}$ ) and trimethylamine nitrogen (TMA-N) contents were determined by the method of Conway, (1950).Non-protein nitrogen was determined according to AOAC, (2005) method. Thiobarbituric acid (TBA) value was estimated according to Tarladgis et al., (1960). Texture attributes of shrimps were evaluated using texture analyser (Lloyd instruments LRX plus, UK) according to the method followed by Anderson et al., (1994). Sensory evaluation of whole head- on- shrimp was assessed by six trained panelist according to the method followed by Jeyakumari et al., (2015) for shrimps. The mean of the scores given by the panel represented the overall acceptability of the shrimps. The score of below 4 was considered as unacceptable. 
Aerobic plate count (APC) and Staphylococcus aureus were determined by the method of FAO, (1992). Escherichea coli and Enterobacteriaceae were determined according to BAM, (2002). Enterococci were determined according to the method followed by Koutsoumanis and Nychas (1999).

\section{Statistical analysis}

One way Analysis of Variance (ANOVA) was performed using Statistical Package for Social Science (SPSS) software version 16.0.(SPSS Inc, Chicago, Llinois, USA) for the obtained results. The data were analyzed at the significance level of $95 \%(\mathrm{p}<0.05)$ by using Tukey multiple range test.

\section{Results and Discussion}

\section{Proximate and fatty acid composition of white shrimp}

In the present study white shrimp had moisture, protein, fat and ash content of 78.45 $\pm 0.18 \%, 18.8 \pm 0.23 \%, 1.28 \pm 0.09 \%, 1.2 \%$, respectively. Results are agreement with earlier researchers reported for shrimp (Gokoglu et al., 2008; Jeyakumari et al., 2015). Fatty acid composition revealed that, white shrimp had higher polyunsaturated fatty acids (PUFA) content (44.73\%) followed by saturated fatty acids $(35.45 \%)$ and monounsaturated fatty acids (19.65\%). Lin et al., (2003) also observed similar results in white shrimp.

\section{Moisture, pH and Non Protein Nitrogen Content (NPN)}

In the present study, moisture content showed increased trend in white shrimp during ice storage (Fig. 1). Jeyakumari et al., (2015) also observed similar results for white shrimp which was iced at various time intervals and explained that increasing moisture content during progressive storage may be due to the loss of proteins and other soluble substances. $\mathrm{pH}$ of shrimp meat showed increased trend in pH during storage (Fig. 2). Dileep et al., (2005) reported that increase $\mathrm{pH}$ in muscle foods is associated with the accumulation of basic compounds, mainly resulted from microbial action. However, PS and SMB treated sample showed less $\mathrm{pH}$ than control. Nirmal and Benjakul (2009) also observed similar results for ferulic acid treated white shrimp and reported that it may be due to during treatment, some of the basic decomposed compounds might be leached out to some extent. In the present study, NPN content showed decreasing trend (610-602 mg $\%)$ during chilled storage in the control (Fig. 3). Jeyakumari et al., (2015) also observed decreasing NPN content in shrimp stored under ice and reported that the changes may be due to the leaching of soluble compounds in the muscle. However, PS and SMB treated sample showed a significant $(\mathrm{P}<0.05)$ increase in NPN content during storage. Sikorski et al., (1990) found that the contribution of higher NPN content in seafood could arise from free amino acids, low molecular weight peptide, urea and trimethylamine oxide.

\section{Total Volatile Base Nitrogen (TVB-N) and Trimethylamine Nitrogen (TMA-N)}

Initial TVB-N content of shrimp meat was $2.8 \mathrm{mg} \mathrm{N} / 100 \mathrm{~g}$. In the present study, total volatile basic nitrogen content in shrimp meat showed increasing trend during ice storage (Table 1). Control sample had a TVB-N value of $25.85 \mathrm{mg}$ of TVB-N/100g at the end of $15^{\text {th }}$ day. However, shrimp treated with PS/SMB had a TVB-N value of $20.15 \mathrm{mg}$ of TVB$\mathrm{N} / 100 \mathrm{~g}, \quad 23.15 \mathrm{mg}$ of $\quad$ TVB-N/100g, respectively on day 15 . The TVB value of $<30$ $\mathrm{mg} \mathrm{N} / 100 \mathrm{~g}$ sample is acceptable for consumption the shrimps (Lopez-Caballero et al., 2007). Accordingly, the entire sample had a TVB-N value within the acceptable limit 
during storage. It was observed that TMA content in control sample was absent till $3^{\text {rd }}$ day and there after it exhibited $2.70 \mathrm{mgN} / 100 \mathrm{~g}$ during $6^{\text {th }}$ day and further increased to $7.5 \mathrm{mgN} / 100 \mathrm{~g}$ on $15^{\text {th }}$ day. However, PS and SMB treated sample had a TMA content of $6.50,6.93 \mathrm{mg} \mathrm{N} / 100 \mathrm{~g}$ respectively (Table 1). The TMA value of $10-15 \mathrm{mg} / 100 \mathrm{~g}$ is recommended for the consumption in fish and shell fish product (Connell, 1995). Accordingly, the entire sample is does not crossed the acceptable limit.

\section{Thiobarbituric acid (TBA)}

TBA index is commonly used as a biochemical quality indicator which measures the level of malanoldehyde (MDA) content, a secondary lipid degradation product (Benjakul et al., 2005). Fresh shrimp meat had TBA value of $0.05 \mathrm{mg}$ of $\mathrm{MDA} / \mathrm{kg}$ of sample. In general, TBA value showed increased trend during storage (Fig. 4). In case of control, TBA value reached $0.21 \mathrm{mg}$ of $\mathrm{MDA} / \mathrm{kg}$ on day 15. However, PS, SMB showed lower TBA values of $0.15 \mathrm{mg}$ of $\mathrm{MDA} / \mathrm{kg}, 0.18 \mathrm{mg}$ of malanoldehyde $/ \mathrm{kg}$, respectively on $15^{\text {th }}$ day. The TBA value of $1-2 \mathrm{mg}$ of $\mathrm{MDA} / \mathrm{kg}$ is generally considered as the limit for acceptability of seafoods for human consumption (Connell, 1995). Accordingly, entire sample had an acceptable limit of TBA values.

\section{Textural quality}

Texture is one of the important properties of fish and shell fish whether it is raw or processed because it influences the consumer acceptability. In general, there is significant $(p<0.05)$ decrease in textural properties were observed in all samples during storage (Table 2). Initially, the hardness of shrimp showed $36.95 \mathrm{~N}$ and it was reduced to $28.40 \mathrm{~N}$, $26.35 \mathrm{~N}, 26.80 \mathrm{~N}$, respectively for control, PS,
SMB treated sample at the end of storage. Jeyakumari et al., (2015) reported that decrease trend in textural attributes during progressive storage is due to the proteolysis of meat which is caused by endogenous and microbial enzyme. Cohesiveness of the shrimp meat does not showed significant $(p>0.05)$ difference in both control and treated samples during storage which indicates that shrimp meat is not undergone any internal structural changes during storage. Springiness or elasticity of shrimp meat decreased significantly $(\mathrm{p}<0.05)$ which indicates the shrimp meat gets reducing its elasticity during storage. In the present study, chewiness values showed significant $(\mathrm{p}<0.05)$ decrease in both control and treated sample during storage. It may be due to muscle softening and degradation.

\section{Microbial quality}

Total aerobic mesophilic bacterial counts of newly caught farmed white shrimp ( $L$. vannamei) was close to or lower (4.3log10) than the value recommended $\left(5.0^{*} 10^{5} \mathrm{cfu} / \mathrm{g}\right)$ for raw fish and shell fish (ICMSF, 1998). Lalitha and Surendran (2006) also observed similar results for cultured Pennaeus monodon and Macrobrachium rosenbergii. White shrimps treated with PS showed reduced total aerobic bacterial countonday3, there after it showed significant $(p<0.05)$ reduction on $6^{\text {th }}$ day and then, gradually increased. Lakshmanan et al., (2003) reported that initial reduction of microbial count might be due to bacterial species are not able to grow or at low temperatures. Gradual increase in total bacterial counts during storage may be due to the adaption of some of the bacterial species to chill temperatures (Lalitha and Surendran, 2006). Ninan et al., (2003) also observed similar results for cultured prawn kept under chilled storage. 
Table.1 Changes in TVB-N and TMA-N of white shrimp (Litopenaeus vannamei) during ice storage

\begin{tabular}{|c|c|c|c|c|c|}
\hline Sample/Days & $\mathbf{0}$ & $\mathbf{3}$ & $\mathbf{6}$ & $\mathbf{9}$ & $\mathbf{1 2}$ \\
\hline \multicolumn{5}{|c|}{ TVB-N $(\mathbf{m g} \%)$} \\
\hline $\mathrm{T}_{\mathrm{C}}$ & $2.8 \pm 0.02$ & $6.78 \pm 0.01$ & $11.13 \pm 0.15$ & $16.23 \pm 0.02$ & $21.74 \pm 0.03$ \\
\hline $\mathrm{T}_{\mathrm{P}}$ & $2.8 \pm 0.02$ & $8.29 \pm 0.03$ & $13.49 \pm 0.10$ & $15.87 \pm 0.03$ & $18.23 \pm 0.03$ \\
\hline $\mathrm{T}_{\mathrm{S}}$ & $2.8 \pm 0.02$ & $8.36 \pm 0.02$ & $17.20 \pm 0.08$ & $18.43 \pm 0.02$ & $19.52 \pm$ \\
& \multicolumn{5}{|c}{0.01} \\
\hline \multicolumn{5}{|c|}{ TMA (mg\%) } \\
\hline $\mathrm{T}_{\mathrm{C}}$ & Nil & Nil & $2.7 \pm 0.01$ & $2.7 \pm 0.02$ & $6.9 \pm 0.05$ \\
\hline $\mathrm{T}_{\mathrm{P}}$ & Nil & $2.7 \pm 0.02$ & $3.4 \pm 0.02$ & $4.62 \pm 0.14$ & $6.52 \pm 0.02$ \\
\hline $\mathrm{T}_{\mathrm{S}}$ & Nil & $2.7 \pm 0.01$ & $4.2 \pm 0.00$ & $5.5 \pm 0.10$ & $6.0 \pm 0.04$ \\
\hline
\end{tabular}

Results are mean $\pm \mathrm{SD}, \mathrm{n}=3 ; \mathrm{T}_{\mathrm{C}^{-}}$Control; $\mathrm{T}_{\mathrm{P}^{-}}$Potassium sorbate treated; $\mathrm{T}_{\mathrm{S}^{-}}$Sodium metabisulphite treated

Table.2 Changes in texture of white shrimp (Litopenaeus vannamei) during ice storage

\begin{tabular}{|c|c|c|c|c|c|c|}
\hline $\begin{array}{c}\text { Storag } \\
\text { e days }\end{array}$ & $\begin{array}{c}\text { Sample/ } \\
\text { Paramete } \\
\mathbf{r}\end{array}$ & $\begin{array}{c}\text { Hardness } \\
\mathbf{1}\end{array}$ & $\begin{array}{c}\text { Hardness 2 } \\
(\mathbf{N})\end{array}$ & Cohesiveness & $\begin{array}{c}\text { Springiness } \\
(\mathbf{m m})\end{array}$ & $\begin{array}{c}\text { Chewiness } \\
(\mathbf{k g f . m m})\end{array}$ \\
\hline $\mathbf{0}$ & $\mathrm{T}_{\mathrm{C}}$ & $38.95 \pm$ & $29.85 \pm 0.10$ & $0.18 \pm 0.12$ & $2.89 \pm 0.20$ & $2.52 \pm 0.25$ \\
& & 0.25 & & & & \\
\hline & $\mathrm{T}_{\mathrm{P}}$ & $36.11 \pm$ & $30.45 \pm 0.33$ & $0.15 \pm 0.04$ & $2.43 \pm 0.05$ & $1.65 \pm 0.18$ \\
\hline & & 0.10 & & & & \\
\hline $\mathbf{3}$ & $\mathrm{T}_{\mathrm{S}}$ & $36.75 \pm 0.20$ & $24.68 \pm 0.25$ & $0.12 \pm 0.20$ & $2.42 \pm 0.14$ & $1.72 \pm 0.25$ \\
\hline & $\mathrm{T}_{\mathrm{C}}$ & 38.93 & $29.85 \pm 0.10$ & $0.18 \pm 0.12$ & $2.62 \pm 0.32$ & $2.35 \pm 0.12$ \\
\hline & & \pm 0.15 & & & & \\
\hline & $\mathrm{T}_{\mathrm{P}}$ & $36.11 \pm 0.10$ & $27.79 \pm 0.15$ & $0.15 \pm 0.05$ & $2.43 \pm 0.05$ & $1.35 \pm 0.23$ \\
\hline $\mathbf{6}$ & $\mathrm{T}_{\mathrm{S}}$ & $32.22 \pm 0.20$ & $22.68 \pm 0.18$ & $0.12 \pm 0.08$ & $2.42 \pm 0.14$ & $1.75 \pm 0.10$ \\
\hline & $\mathrm{T}_{\mathrm{C}}$ & 38.80 & $26.47 \pm 0.30$ & $0.18 \pm 0.10$ & $2.55 \pm 0.22$ & $1.79 \pm 0.18$ \\
\hline & & \pm 0.32 & & & & \\
\hline & $\mathrm{T}_{\mathrm{P}}$ & $31.96 \pm 0.10$ & $22.79 \pm 0.20$ & $0.16 \pm 0.05$ & $2.46 \pm 0.05$ & $1.35 \pm 0.10$ \\
\hline $\mathbf{9}$ & $\mathrm{T}_{\mathrm{S}}$ & $29.35 \pm 0.20$ & $19.69 \pm 0.35$ & $0.14 \pm 0.02$ & $2.15 \pm 0.05$ & $1.30 \pm 0.15$ \\
\hline & $\mathrm{T}_{\mathrm{C}}$ & $35.35 \pm 0.25$ & $24.18 \pm 0.45$ & $0.20 \pm 0.02$ & $2.20 \pm 0.14$ & $1.62 \pm 0.40$ \\
\hline & $\mathrm{T}_{\mathrm{P}}$ & $30.85 \pm 0.20$ & $25.45 \pm 0.15$ & $0.17 \pm 0.04$ & $2.55 \pm 0.15$ & $1.30 \pm 0.02$ \\
\hline $\mathbf{1 2}$ & $\mathrm{T}_{\mathrm{S}}$ & $26.75 \pm 0.35$ & $19.71 \pm 0.25$ & $0.15 \pm 0.00$ & $2.15 \pm 0.18$ & $1.25 \pm 0.05$ \\
\hline & $\mathrm{T}_{\mathrm{C}}$ & 31.45 & $22.10 \pm 0.42$ & $0.18 \pm 0.02$ & $2.30 \pm 0.10$ & $1.43 \pm 0.32$ \\
\hline & & \pm 0.28 & & & & \\
\hline & $\mathrm{T}_{\mathrm{P}}$ & $24.98 \pm 0.25$ & $18.82 \pm 0.20$ & $0.23 \pm 0.00$ & $2.40 \pm 0.20$ & $1.25 \pm 0.25$ \\
\hline & $\mathrm{T}_{\mathrm{S}}$ & $24.53 \pm 0.35$ & $18.18 \pm 0.15$ & $0.23 \pm 0.02$ & $2.10 \pm 0.35$ & $1.20 \pm 0.15$ \\
\hline
\end{tabular}


Fig.1 Changes in moisture content of white shrimp (Litopenaeus vannamei) during chilled storage

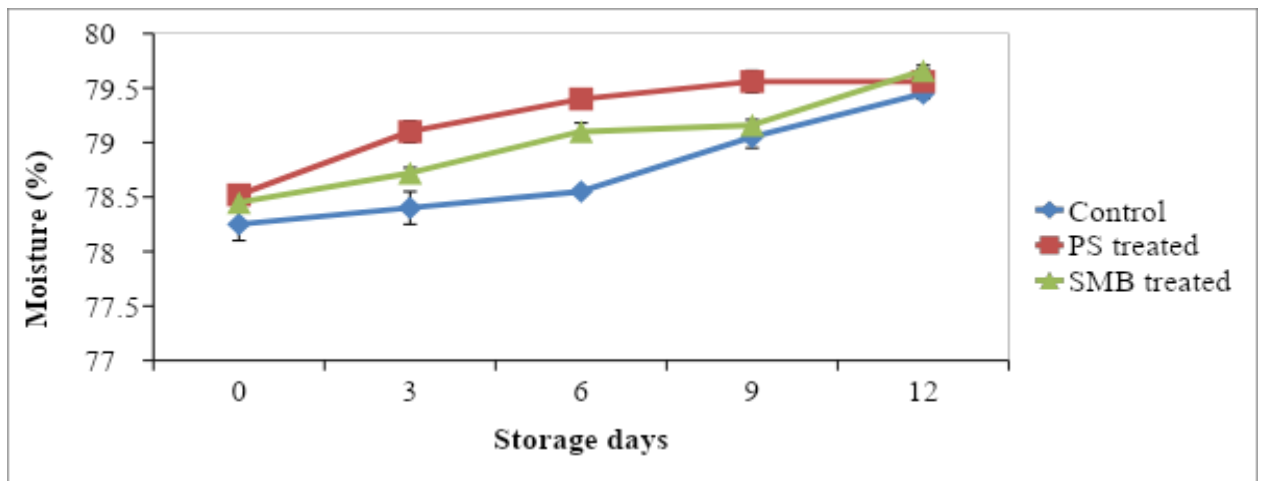

Fig.2 Changes in $\mathrm{pH}$ values of white shrimp (Litopenaeus vannamei) during chilled storage

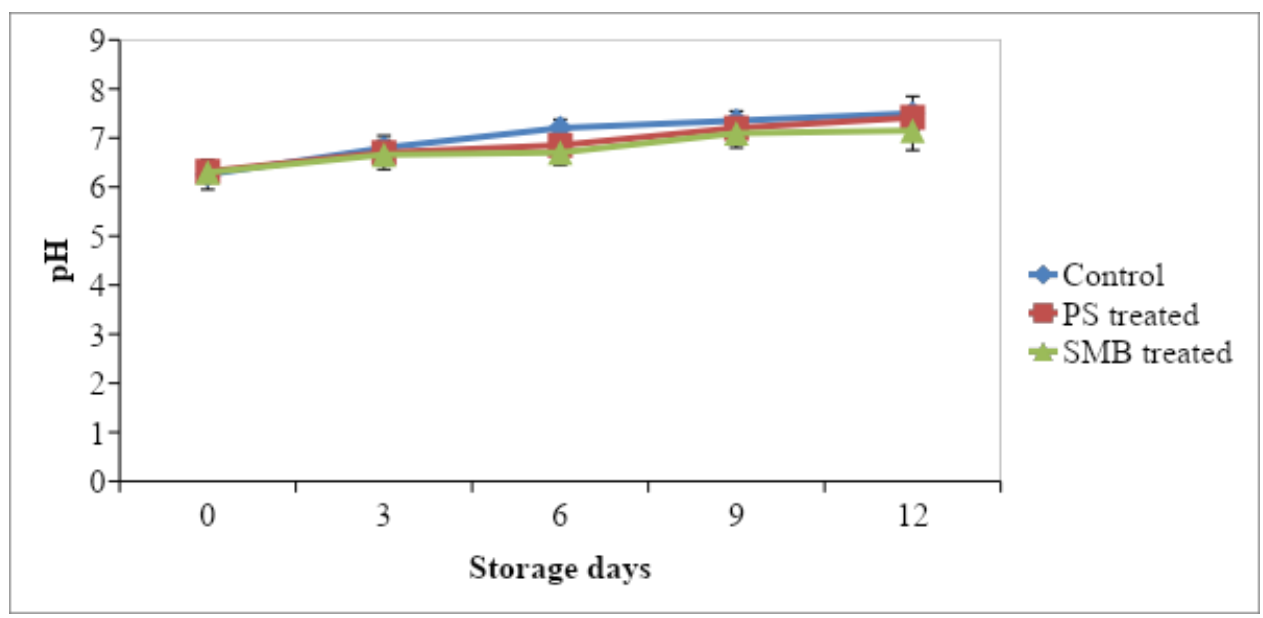

Fig.3 Changes in Non protein nitrogen (NPN) values of white shrimp (Litopenaeus vannamei) during chilled storage

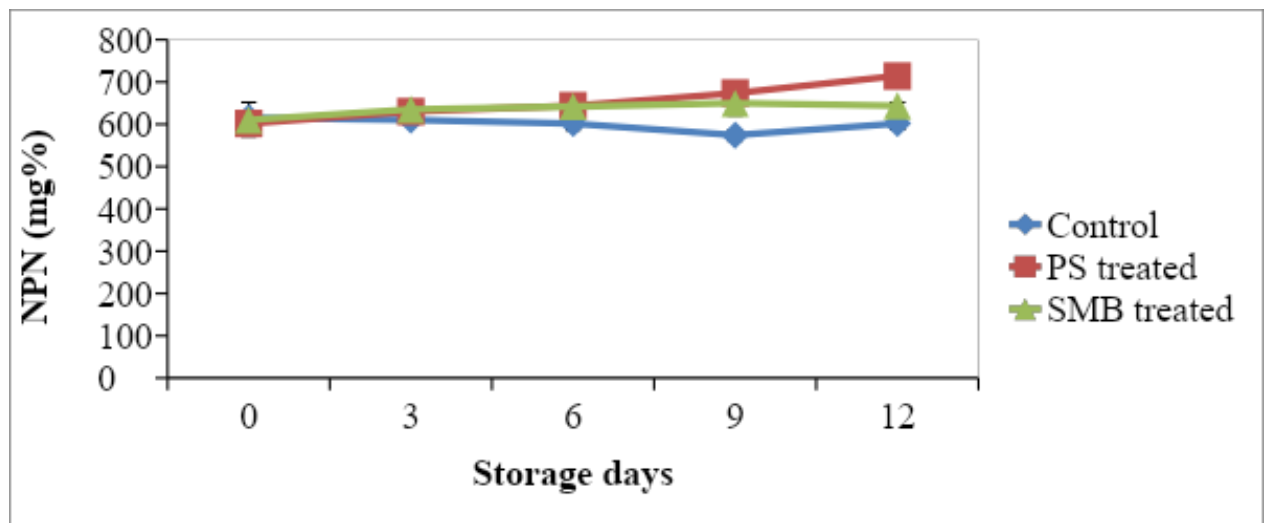


Fig.4 Changes in thiobarbituric acid (TBA) values of white shrimp (Litopenaeus vannamei) during chilled storage

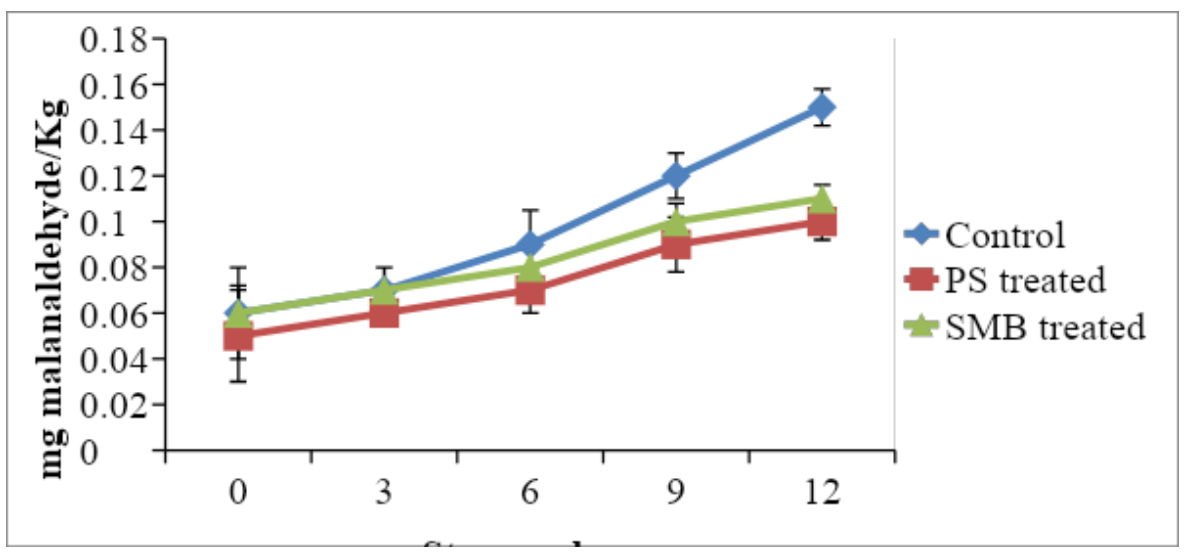

Fig.5 Changes in overall acceptability of white shrimp (Litopenaeus vannamei) during chilled storage

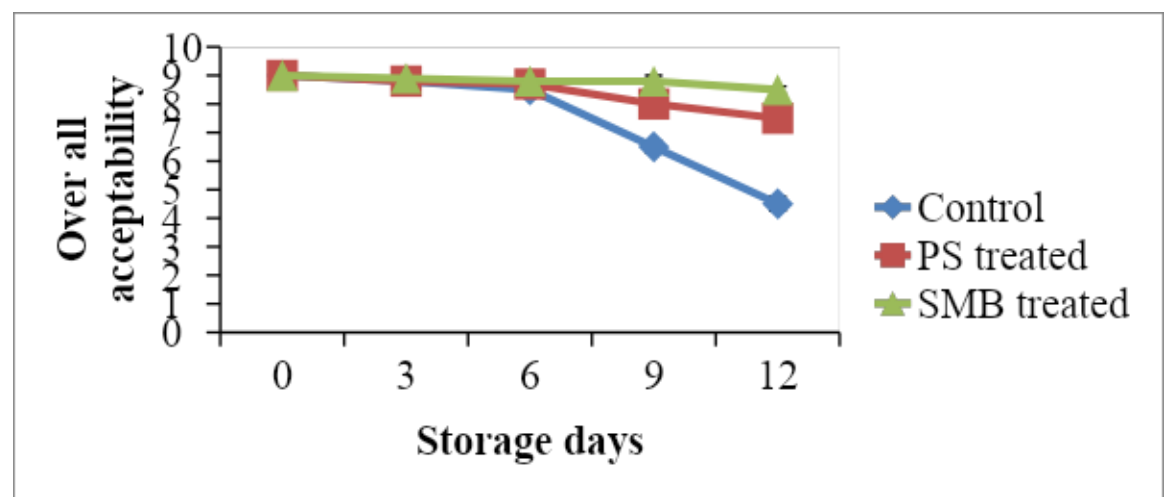

Results showed that aerobic counts gradually increased to5.2 $\log 10$ on $12^{\text {th }}$ day for control sample (Fig. 3). In case of PS, SMB treated sample, TPC reached $4.4 \log 10,4.9 \log 10$, respectively on day 12 . Moreover, both PS, SMB treated sample total bacterial count reached $5.1 \log 10,5.5 \log 10$, respectively on day 15. Results from the study indicate that among the two treatments, PS was effective in reducing the bacterial count under ice storage.

\section{Overall Acceptability}

Fresh shrimp had natural characteristics of odor, bright colour and excellent textural properties with a score of 9.0. There is no significant $(p<0.05)$ changes in over all acceptability till $6^{\text {th }}$ day. After $6^{\text {th }}$ day, control sample lost its freshness and fetch the score of $6.5,4.5$ on $9^{\text {th }}$ and $12^{\text {th }}$ day respectively (Fig. 5). Basavakumar et al., (1998) observed similar results for Penaeus monodon stored under ice. In case of PS treated sample exhibited slightly black colour and loose head on day 12 with score of 6.5. Thereafter slight yellowness on the shell and complete loosening of head was observed and rejected on $15^{\text {th }}$ day with the score of 4.5. It was observed that over all acceptability of SMB treated sample had higher score of 6.5 till $15^{\text {th }}$ day. However, the samples were rejected based on the microbial quality.

It can be concluded that biochemical quality indices such as total volatile base nitrogen, trimethylamine, and thiobarbituric acid 
content were within acceptable limit in the white shrimp under ice storage. Microbial and sensory analysis revealed that control sample had a shelf life of $9^{\text {th }}$ day. In case of potassium sorbate, sodium metabisulphite treated samples remains acceptable up to $12^{\text {th }}$ day. Results indicated that use of potassium sorbate and sodium metabisulphite could extend the shelf-life of white shrimp to three more days than control under ice storage.

\section{References}

Anderson, U.B., Stomsnes, A.N., Thomassen, M.S., Steinsholt, K. 1994. Fillet gaping in farmed Atlantic salmon. North J. Agri. Sci., 8: 165-179

AOAC.2005. Official Methods of Analysis of AOAC International, $17^{\text {th }}$ ed. Gaithersburg, MD, USA: Association of Analytical Communities.

BAM. 2002. Enumeration of Escherichia coli and the Coliform Bacteria. In: Bacteriological Analytical Manual, Chapter 4; United States Food and Drug Administration.

Basavakumar, K.V., Bhaskar, N., Ramesh, A.M., Reddy, G.V.S. 1998. Quality changes in cultured tiger shrimp (Penaeus monodon) during ice storage. J. Food Sci. Tech., 35(4): 305-309

Benjakul, S., Visessanguan, W., Tanaka, M. 2005. Properties of phenoloxidase isolated from the cephalothorex of kuruma prawn (Penaeus japonicus). J. Food Biochem., 29: 470-485

Campanone, L.A., Roche, L.A., Salvadori, V.O., Mascheroni, R.H. 2002. Monitoring of weight losses in meat products during freezing and frozen storage. Food Sci. Tech. Int., 8(4): 229-238

Chen, D.D., Meng, X.L., Xu, J.P., Yu, J.Y., Meng, MX, Wang. J. 2013. PcLT, a novel C-type lectin from Procambarusclarkii, is involved in the innate defense against
Vibrio alginolyticus and WSSV. Dev. Comp. Imm., 39: 255-264

Connell, J.J. 1995. Quality deterioration and extrinsic quality defects in raw material. In: Control of fish quality. $4^{\text {th }}$ edn. Fishing News Books Ltd. Survey, England. 241

Conway, E.J. 1950. Micro-diffusion analysis and volumetric error. $5^{\text {th }}$ edn. Lockwood and Son Ltd, London. 467-472

Dileep, A.O, Shamasundar, B.A, Binsi, P.K., Badii, F., Howell, N.K. 2005. Effect of Ice Storage on the Physicochemical and Dynamic Viscoelastic Properties of Ribbonfish (Trichiurus spp.) Meat. J. Food Sci., 70: E537-E545

FAO.1992. Manual of food quality control, 4.Rev.1. Microbial analysis. FAO Food and Nutrition paper. Food and Agriculture Organization of the United Nations, Rome.

Folch, J., Lees, M., Sloane-Stanley, G.H. 1957. Simple method for purification and isolation of lipid (total) from animal tissue. J. Biol. Chem., 225: 492

Gokoglu, N., Yerlikaya, P., Gokoglu, M. 2008. Mini-review. Trace elements in edible tissue of three shrimp species (Penaeus semisulcatus, Parapenaeus longirostris and Paleomonserratus). J. Sci. Food Agric., 88: 175-178

International Commission on Microbiological Specifications for Foods (ICMSF).1998. Microorganisms in foods, 6. Microbial ecology of food commodities. Baltimore: Blackie Academic \& Professional.

Jeyakumari A, Remya S, Jesmi Debbarma, Ravishankar C N, Zynudheen A A, George Ninan, Venkateshwarlu Ronda, Lalitha K V (2015) Effect of delayed icing on the quality of white shrimp (Litopenaeus vannamei) during chilled storage. J. Food Process Pres., DOI:10.1111/jfpp.12539.

Koutsoumanis, G.K, Nychas, J.E.1999. Chemical and sensory changes associated with microbial flora of Mediterranean 
bogue (Boopsboops) stored aerobically at 0, 3, 7, and $10^{\circ} \mathrm{C}$. App. Env. Microbiol, 65: 698-706

Lakshmanan, R., Piggott, J.R.,Paterson. A.2003. Potential applications of high pressure for improvement in salmon quality. Trends Food Sci. Tech., 14(9): 354-363

Lalitha, K.V., Surendran, P.K. 2006. Microbiological changes in farm reared freshwater prawn (Macrobrachium rosenbergii de Man) in ice. Food Cont., 17: 802-807

Lopez-Caballero ME, Martinez-Alvarez O, Gomez-Guillen MC, Montero P (2007) Quality of thawed deepwater pink shrimp (Parapenaeus longirostris) treated with melanosis-inhibiting formulations during chilled storage. Int. J. Food Sci., 42: 1029-1038

Manju, S., Srinivasagopal, T.K., Leema Jose, Ravishankar, C.N., Ashok Kumar, K. 2007. Nucleotide degradation of sodium acetate and potassium sorbate dip treated and vacuum packed Black Pomfret (Parastromateus niger) and Pearlspot (Etropluss uratensis) during chill storage. Food Chem., 102: 699-706

Montero P, Lopez-Caballero ME, PerezMateos M (2001) The effect of inhibitors and high pressure treatment to prevent melanosis and microbial growth on chilled prawns (Penaeus japonicus). J. Food Sci., 66:1201-1206

MPEDA (2018) Marine product export development of authority. Press information Bureau, Government of India,
Ministry of commerce and Industry. (www.mpeda.gov.in/2017-18. pdf)

Ninan, G., Bindu, J., Asok Kumar, K., Joseph, J. 2003. Biochemical changes in the chilled storage of Macrobrachium rosenbergii (de Man) and the evaluation of freshness. In paper presented at the International Symposium on Freshwater Prawns, 21- 23 August. College of Fisheries Panangad, Cochin.

Nirmal, N.P., Benjakul, S. 2009. Effect of ferulic acid on inhibition of polyphenol oxidase and quality changes of pacific white shrimp (Litopeneaus vannamei) during iced storage. Food Chem., 116: 323- 331

Sikorski, Z.E, Kolakowska, A., Pan, B.S. 1990 The nutritive composition of the major groups of marine food organisms. In: Seafood: resources, nutritional composition and preservation. Sikorski, Z. E. (Ed.) CRC Press, Florida. pp. 29-54

Tarladgis, G.B., Watts, M.B., Younathan, T.M. 1960. A distillation method for the quantitative determination of malonaldehyde in rancid foods. J. Amer. Oil Chem. Soci., 37: 44-50

Thomas, L.V. 2000. Preservatives. Sorbic acid. In:Encyclopedia of food microbiology. Robinson, R. K., Batt, C. A., and Patel, C. (Eds.) Academic Press, New York. pp. 1769-1776

Zeng, Q.Z., Thorarinsdottir, K.A., Olafsdottir, G. 2005. Quality changes of shrimp (Pandalus borealis) stored under different cooling conditions. J. Food Sci., 70(7): 459-466

\section{How to cite this article:}

Jeyakumari, A., Jesmi Debbarma, S. Remya, C.N. Ravishankar, A.A. Zynudheen, George Ninan and Lalitha, K.V. 2019. Quality Changes of White Shrimp (Litopenaeus vannamei) Treated with Potassium Sorbate and Sodium Metabisulphite: A Comparative Study. Int.J.Curr.Microbiol.App.Sci. 8(11): 1331-1339. doi: https://doi.org/10.20546/ijcmas.2019.811.156 